\title{
Oral glucose tolerance test in pregnant women and factors affecting their decisions
}

\section{Gebelerde oral glukoz tolerans testine bakış ve etkilleyen faktörler}

\author{
Emre Destegüil ${ }^{1}$, Servet Gençdal ${ }^{2}$
}

'Nigde Omer Halisdemir University Medical Faculty Training and Research Hospital Department of Obstetrics and Gynecology; Nigde, Turkey 2Department of Obstetrics and Gynaecology, İzmir Katip Çelebi University, Atatürk Research and Training Hospital, İzmir, Narlıdere, Turkey Corresponding author: Emre Destegül, MD, Nigde Omer Halisdemir University Medical Faculty Training and Research Hospital Department of Obstetrics and Gynecology; Nigde, Turkey

E-mail: destegulemre@ohu.edu.tr

Received/Accepted: December 16, 2019 / July 02, 2020

Conflict of interest: There is not a conflict of interest.

\section{SUMMARY}

Objective: In this study, we aimed to investigate the demographic findings and the reasons for not accepting the oral glucose tolerance test during pregnancy.

Method: This study was carried out on the pregnants in Nigde University Obstetrics and Gynecology Clinic. The study was performed with pregnants to whom OGTT was recommended in the 24-28 gestational weeks, but who did not accept the test. Pregnant women were asked questionnaires prepared by our clinic and the answers were recorded.

Frequency, percentage, mean, standard deviation, Kruskal-wallis and Mann-Whitney U test and Spearman correlation analysis were used for data analysis.

Results: A total of 299 pregnant women were included in the study. Mean age of the pregnant women was $26.88 \pm 5.59$ years. Mean gestational week was $25.4 \pm 3.12$. When the reasons of not having OGTT in pregnant women who had OGTT in their previous pregnancies are examined, $42.9 \%$ thought the test was unnecessary, $4.3 \%$ thought it was difficult to perform the test, $24.5 \%$ said they read news about the harmful effects of the test in the press, $12.3 \%$ said because the doctor did not recommend the test, $12.3 \%$ said they did not have regular follow-up, 3.7\% stated that they did not take the test because they were not informed sufficiently about the test.

Conclusions: In conclusion, this study is an important study in terms of revealing the prejudices of pregnant women who applied to our clinic in Nigde province, even though there are few subjects.

Keywords: Pregnancy, gestational diabetes, oral glucose tolerance test
Emre Destegül

Servet Gençdal

ORCID IDs of the authors:

E.D. 0000-0001-5726-0223

S.G. 0000-0002-7660-4543

\section{ÖZET}

Amaç: Bu çalışmamız da gebelikte glukoz yükleme testini kabul etmeyen olguların demografik bulguları ile testi kabul etmeme nedenlerinin incelenmesi amaçlanmıștır.

Yöntem: Bu çalışma Niğde Üniversitesi Kadın Hastalıkları ve Doğum Polikliniğine başvuran, 24-28. gebelik haftalarında OGTT önerilen, ancak testi kabul etmeyen gebelerle yapıldı. Gebelere kliniğimiz tarafından oluşturulan anket sorular soruldu ve cevaplar kaydedildi. Verilerin analizinde frekans, yüzde, ortalama, standart sapma, Kruskal-wallis ve Mannwhitney U testi ve Spearman korelasyon analizi kullanıld1. 
Bulgular: Çalışmaya toplam 299 gebe dahil edildi. Gebelerin yaş ortalaması 26.88 \pm 5.59 idi. Ortalama gebelik haftası 25.4 \pm 3.12 idi. Önce ki gebeliklerinde OGTT yaptıran gebelerin şimdi ki gebeliğinde OGTT yaptırmama nedenleri incelendiğinde $\% 42.9$ 'si testin gereksiz olduğunu düşündüğü için, $\% 4.3$ 'ü testin uygulanmasının zor olduğunu düşündüğü için, \%24.5'i basın da testin zararlı olduğu söylendiği için, \%12.3'ü doktoru tarafindan testin önerilmediği için, \%12.3 düzenli takiplerinin yaptırmadığı için, \%3.7 test hakkında yeterince bilgilendirilmediği için testi yaptırmadığını ifade etti. Sonuç: Sonuç olarak bu çalışma az sayıda denekle olsa da Niğde ilimiz de kliniğimize başvuran gebelerin şeker yükleme testine bakışlarını ve ön yargılarını ortaya koyması açısından önemli bir çalışmadır.

Anahtar sözcükler: Gebelik, gestasyonel diyabet; şeker yükleme testi

\section{INTRODUCTION}

Gestational diabetes mellitus (GDM) is the most common endocrinopathy during pregnancy and affects approximately 6-7\% of pregnant women. In pregnant women without risk factors, GDM can be diagnosed with oral glucose tolerance test at 24-28 weeks of gestation and fetal, neonatal and maternal complications (congenital abnormalities, macrosomia, perinatal death, birth trauma, etc.) that may develop due to GDM can be prevented ${ }^{1}$. Women diagnosed with GDM are willing to have treatment during pregnancy, but do not show enough interest in pregnancy glucose tolerance testing ${ }^{2,3}$. Patients referred to the oral glucose tolerance test (OGTT), especially those in the high socioeconomic category, have a higher acceptance rate; however, this rate is lower in patients with low socio-economic status ${ }^{4}$. However, in recent years, there have been reports in various media outlets that OGTT during pregnancy may be harmful to the fetus. It is noteworthy that the desire for the glucose load test during pregnancy decreased regardless of socioeconomic status and that pregnant women were skeptical about this test because of these media news. The awareness of the patients about the information they obtain through the media is very high. In particular, statements made by famous people may affect their health decisions positively or negatively. It is possible that this situation will sometimes cause trust problems between obstetricians and mothers and at the same time it may endanger the pregnancy process. In this study, we aimed to investigate the the reasons for refusal of oral glucose tolerance test during pregnancy.

\section{MATERIAL AND METHODS}

This study was carried out in Niğde University Obstetrics and Gynecology Clinic with 299 pregnant patients. Ethical approval of the study was obtained from the Ethics Committee of Niğde University (Ethics decision no:2019/25) and written permission was obtained from the institution where the study would be conducted. Pregnants participating in the study were informed about the purpose of the study and their written informed consent was obtained. Pregnant women were asked the questions, created by our clinic, by a person (Emre Destegül) in a face-to-face setting; including obstetric history, gestational week, working status, education level, type of health insurance, history of gestational diabetes mellitus, history of macrosomic fetus, previous history of having OGTT and the reasons for not having OGTT in her current pregnancy (a-I do not believe that a-test is necessary, b- I do not want to have it because it is difficult, c-I do not want to do because some media organ says that the test (sugar) may harm my baby, d-the test was not recommended by my doctor, e-I could not have my pregnancy follow-ups regularly, f-I was not informed enough by my doctor about the test), and the answers were recorded. In our clinic, single-step 75 g OGTT is recommended for pregnant women. Patients with a history of DM before pregnancy were excluded from the study.

\section{Statistical Analysis}

SPSS (version 24.0) package program was used for the evaluation of data. Frequency, percentage, mean, standard deviation, Kruskal-wallis and Mann-Whitney U test and Spearman correlation analysis were used for data analysis. Significance level was accepted as $\mathrm{p}<0.05$.

\section{RESULTS}

A total of 299 pregnant women were included in the study. Mean age of the pregnant women was $26.88 \pm 5.59$ years. The mean gestational week was $25.4 \pm 3.12$. The demographic findings of the patients are summarized in Table 1. Table 2 shows the reasons of patients who did not want to have test. And the most common reason was found to be the belief that the test was unnecessary. OGTT rate was $45.4 \%$ in the cases who were included in the study. When the reasons of not having OGTT in pregnant women who had OGTT in their previous pregnancies are examined $42.9 \%$ thought the test was unnecessary, $4.3 \%$ thought it was difficult to perform the test, $24.5 \%$ said they read news about the harmful effects of the test in the press, $12.3 \%$ refused to have test because the doctor did not recommend it, $12.3 \%$ did not have regular follow- 
up, $3.7 \%$ stated that they did not take the test because they were not informed sufficiently about the test. Comparison of pregnant women who had OGTT and who did not have OGTT in their previous pregnancy showed, patients who had OGTT in previous pregnancies were more lean not to take test the in the current pregnancy because of it is difficult to perform and this difference was statistically significant $(\mathbf{p = 0 . 0 0 8})$. When the educational status of the cases and the reasons for not having OGTT in their current pregnancies were examined, it was seen that non-university graduates thought that the test was difficult to be performed. This difference was statistically significant when compared with pregnant women who graduated from university $(\mathbf{p}=\mathbf{0 . 2 5})$. Among the pregnant women who graduated from university most common reason for refusing the OGTT was the news in media which were said the test was harmful $(23.1 \%)$. However, this situation was not statistically significant when compared with nonuniversity graduates. When the pregnant women with and without GDM history were compared in terms of the reasons for not having OGTT in their current pregnancy, the rate of not taking the test was found statistically significant because they thought the test was unnecessary $(\mathbf{p}=\mathbf{0 . 0 5 0}) .43 .1 \%$ of those without GDM history stated that they thought the test was unnecessary. The most common reason $(40 \%)$ for rejecting OGTT in pregnant women with a history of GDM was the various media news which were reported OGTT was harmful. When this situation was compared with non-GDM pregnant women, the difference was found to be statistically significant. $(\mathbf{p}=\mathbf{0 . 0 5 1})$.

Table 1: Demographic Findings of Patients.

\begin{tabular}{|l|c|c|}
\hline (N= 299) & $\mathbf{n}$ & $\mathbf{\%}$ \\
\hline Age & $26.88 \pm 5.59$ & \\
\hline Gestational Weeks & $25.4 \pm 3.12$ & 27.4 \\
\hline Parity Primipar & & 72.6 \\
\hline \multicolumn{1}{|c|}{ Multipar } & 217 & \\
\hline BMI & $28.14 \pm 4.19$ & 72.9 \\
\hline Previous Birth Method & & 27.1 \\
\hline Vaginal Birth & 218 & 5 \\
\hline Cesarean Section & 81 & 1.67 \\
\hline Previous GDM History & 15 & 17.7 \\
\hline DM Before Pregancy & 5 & 95.6 \\
\hline DM History in family & 53 & 4.4 \\
\hline Health Insurrance Status & & \\
\hline Yes & 286 & 2.34 \\
\hline No & 13 & 19.7 \\
\hline Education Status & & 32.1 \\
\hline Illiterate & 7 & 24 \\
\hline Primary School Graduate & 59 & 21.7 \\
\hline Secondary School Graduate & 96 & \\
\hline High School Graduate & 72 & 45.4 \\
\hline University Graduate & 65 & 54.6 \\
\hline $\begin{array}{c}\text { OGTT History in previous } \\
\text { Pregnacy }\end{array}$ & & \\
\hline Yes & 136 & \\
\hline No & 163 & \\
\hline
\end{tabular}

BMI: Body Mass Index, GDM: Gestational Diabetes Mellitus, DM: Diabetes Mellitus,OGTT: Oral Glucose Tolerance Test 
Table 2: Patients' reasons for rejecting to perform OGTT

\begin{tabular}{|l|c|c|}
\hline Reason (N=299) & n & \% \\
\hline Because it is unnecessary & 122 & 40.8 \\
\hline Because it is difficult to performed & 25 & 8.4 \\
\hline $\begin{array}{l}\text { Because it was said harmful by } \\
\text { way of media }\end{array}$ & 62 & 13 \\
\hline $\begin{array}{l}\text { Because it was not recommended } \\
\text { by my doctor }\end{array}$ & 39 & 13.7 \\
\hline $\begin{array}{l}\text { Because I could not make my } \\
\text { follow up regularly }\end{array}$ & 41 & 3.3 \\
\hline $\begin{array}{l}\text { Because I was not informed } \\
\text { sufficiently }\end{array}$ & 10 & \\
\hline
\end{tabular}

\section{DISCUSSION}

The most common reason for refusing to perform the OGTT in our study was found as patients belief that test is unnecessary. Pregnant women who had OGTT in their previous pregnancies were found to think that the most common reason for not having OGTT in their current pregnancy (43\%) was that the test was unnecessary. The most common reason for rejecting OGTT in pregnant women with a history of GDM was that the test was reported to be harmful in various media organs. When the pregnant women with and without GDM history were compared in terms of the reasons for not having OGTT in their current pregnancy, the rate of not taking the test was found to be statistically significant because they thought the test was unnecessary. This may be due to patients' lack of knowledge about GDM related pregnancy complications or patients' did not face any GDM related pregnancy complications during previous pregnancies. Because patients with a history of GDM are seven times more likely to develop type 2 diabetes than women without a history of GDM ${ }^{5}$. These patients also carry the risk of early diabetes mellitus in subsequent pregnancies. In the study of Ekelund et al. showed that $51 \%$ of patients with GDM had impaired glucose tolerance and 30\% developed diabetes mellitus within 5 years ${ }^{6}$. The prevalence of gestational DM is around 6-7\% in the USA $^{7}$. The prevalence of GDM generally varies in parallel with the prevalence of type 2 diabetes among different racial and ethnic groups. In our study, we found that the prevalence of GDM was $5 \%$, but in a study made by Aytan $\mathrm{H}$. et al. prevalence of GDM was $2.8^{8}$. Population characteristics (such as the average height and body mass index of the pregnant woman), test methods used for screening, and different diagnostic criteria cause the prevalence of GDM to vary. However, it is known that the prevalence of GDM tends to increase over time due to increasing mean maternal age and weight ${ }^{9-12}$.

Whether everyone should be screened for GDM is a controversial issue. Some experts recommend only high-risk patients should be screened for GDM. Helton et al. stated that it may be appropriate to screen only high-risk patients ${ }^{13}$. Risk factors for GDM include prior impaired glucose tolerance or previous history of GDM, family history, especially first-degree relatives, diabetes, prepregnancy body weight, $\geq 110 \%$ of ideal body weight, or BMI> $30 \mathrm{~kg} / \mathrm{m} 2$ or Excessive weight gain in early adulthood and between pregnancies or excessive weight gain during pregnancy, advanced maternal age (> 25 years),> $4.1 \mathrm{~kg}$ infant before birth, unexplained perinatal loss or malformed infant birth before birth, maternal birth weight $>4$, $1 \mathrm{~kg}$ or $<2.7 \mathrm{~kg}$, the presence of metabolic conditions associated with the development of diabetes, such as the detection of glucosuria at the first prenatal visit, metabolic syndrome, polycystic ovary syndrome, glucocorticoid use, and hypertension. ${ }^{14-16}$. Republic of Turkey Ministry of Health pregnancy management guidelines proposes that GTT screening in low-risk populations should be made between 24 and 28 weeks of pregnancy ${ }^{17}$. Turkish Perinatology Society recommends a single step 75-g diagnostic test for the Turkish population. The association stated that this approach is more appropriate in terms of cost and patient compliance ${ }^{18}$.

Our clinic has also recommended a one-step 75-g diagnostic test for pregnant women between 24 and 28 weeks of gestation, for about one year. In our study, it was seen that among the non-university graduates test is difficult belief was as the most 
common reason for not having OGTT. The possible cause of this condition may be the recommendation of a two-step test before in our clinic or sequential testing (50 gr screening test and then 100 gr diagnostic test) in family health centers. However, the most common reason for refusing the OGTT (23.1\%) among pregnant women who graduated from university was that the test was reported to be harmful in the media. In the study by Karasu Y., it was seen that the frequency of application of oral glucose tolerance test gradually decreased after the explanations made by popular physicians in the media about the possible harmful effects of the test. ${ }^{19}$. It is known that famous people effect on society's value judgments, economic-commercial decision making processes and health perceptions. In the study of Hoffman et al., "Celebrity Impact " on health is summarized as follows. The statements made by the famous person using visual, written or social media or through advertising and sponsorship will have some consequences in the short, medium and long term ${ }^{20}$. This situation can be interpreted as the fact that pregnant women with high sociocultural level follow various media outlets more frequently than those with low educational level and unfortunately, they rely more on this news. However, oral glucose tolarance tests have minor side effects (nausea, vomiting, diarrhea), but have no known major side effects ${ }^{21}$. Therefore, when they assert the harmful effects the test in the media, they should prove these assertions scientifically.

In our study, in order to prevent possible bias for each pregnant woman who does not want to undergo OGTT during 24-28 gestational weeks, at least 10 minutes of time was allocated in a single environment and the questions were asked by the same physician and this could be seen as the strength of our study. However, since our study included only a limited number of pregnant women admitted to our clinic and not having a larger population based study, it is an important limitation. Another limitation of our study is that the knowledge level of the pregnant women about the glucose tolerance test cannot be evaluated comprehensively and the long term outcome of the test cannot be predicted.

In conclusion, this study is an important study in terms of revealing the prejudices of pregnant women who applied to our clinic in Nigde province, even though there are few subjects. Based on these results, we believe that the OGTT will be explained more comprehensively to pregnant women in coordination with the related branch associations under the leadership of the Ministry of Health. It was also understood in this study that the efforts of gynecologists are not sufficient to solve this problem.

\section{REFERENCES}

1. Cundy T, Gamble G, Townend K, et al. Perinatal mortality in Type 2 diabetes mellitus. Diabet Med. 2000;17(1):33-9.

2. Ferrara A, Peng T, Kim C. Trends in postpartum diabetes screening and subsequent diabetes and impaired fasting glucose among women with histories of gestational diabetes mellitus: a report from the Translating Research Into Action for Diabetes (TRIAD) Study. Diabetes Care 2009;32:269-74.

3. Kwong S, Mitchell RS, Senior PA, et al. Postpartum diabetes screening: adherence rate and the performance of fasting plasma glucose versus oral glucose tolerance test. Diabetes Care 2009;32:2242-4.

4. Bandyopadhyay M, Small R, Davey MA. Attendance for postpartum glucose tolerance testing following gestational diabetes among South Asian women in Australia: a qualitative study. $\mathrm{J}$ Womens Health Issues Care 2015;4:1.

5. Bellamy L, Casas JP, Hingorani AD, et al. Type 2 diabetes mellitus after gestational diabetes: a systematic review and meta-analysis. Lancet 2009;373: 1773-9.

6. Ekelund M, Shaat N, Almgren P, et al. Prediction of postpartum diabetes in women with gestational diabetes mellitus. Diabetologia 2010;53:452-7.

7. Moyer VA, U.S. Preventive Services Task Force. Screening for gestational diabetes mellitus: US Preventive Services Task Force recommendation statement. Ann Intern Med 2014;160:414-20.

8. Aytan H, Aytan P, Çalışkan AC, et al. Gestasyonel diabetes mellitus gelişimini öngörmede ilk trimester maternal $\mathrm{Ca}$ 19-9 düzeyleri. Cumhuriyet Tıp Derg 2009; 31: 408-412

9.Abouzeid M, Versace VL, Janus ED, et al. A population-based observational study of diabetes during pregnancy in Victoria, Australia, 19992008.BMJ Open 2014;4:e005394.

10. Feig DS, Hwee J, Shah BR, et al. Trends in incidence of diabetes in pregnancy and serious perinatal outcomes:a large, population based study in Ontario, Canada.1996-2010. Diabetes Care 2014;37:1590-6.

11. Kim SY, Saraiva C, Curtis M, et al. Fraction of gestational diabetes mellitus attributable to overweight and obesity by race/ethnicity, 
California, 2007-2009. Am J Public Health 2013;103:e65-72.

12. Bardenheier BH, Elixhauser A, Imperatore G, et al. Variation in prevalence of gestational diabetes mellitus among hospital discharges for obstetric delivery across 23 states in the United States. Diabetes Care 2013;36:1209-14.

13. Helton MR, Arndt J, Kebede M, et al. Do lowrisk prenatal patients really need a screening glucose challenge test? J Fam Pract. 1997;44(6):556-61.

14. Kim C, Liu T, Valdez R, et al. Does frank diabetes in firstdegree relatives of a pregnant woman affect the likelihood of her developing gestational diabetes mellitus or nongestational diabetes? Am J Obstet Gynecol 2009;201:576.e.16.

15. Hedderson MM, Gunderson EP, Ferrara A. Gestational weight gain and risk of gestational diabetes mellitus. Obstet Gynecol 2010;115:597604.
16. Gibson KS, Waters TP, Catalano PM. Maternal weight gain in women who develop gestational diabetes mellitus. Obstet Gynecol 2012;119:560-5.

17. Riskli Gebelikler Yönetim Rehberi. T.C. Sağlik Bakanlığı Türkiye Halk Sağlığı Kurumu Kadın ve Üreme Sağlığı Daire Başkanlığı, Yayın No: 926. Ankara: T.C. Sağlık Bakanlığı 2014.

18. Şen C, Yayla M, Api O, et al. Diabetes in pregnancy: diagnosis and treatment. Practice Guidelines of Turkish Perinatology Society. Perinatal Journal 2016;24:110-27.

19. Karasu Y. Şeker Yükleme Testine Ne Oldu? Medyanın Halk Sağlığ Üzerine Etkisi. Ankara Eğt. Arş. Hast. Derg. 2018 ; 51/1 : 54-58

20. Hoffman SJ, Mansoor Y, Natt N, et al. Celebrities' impact on health-related knowledge, attitudes, behaviors, and status outcomes: protocol for a systematic review, meta-analysis, and metaregression analysis. Syst Rev. 2017;6(1):13.

21. Committee on Practice B-O. Practice Bulletin No. 180: Gestational Diabetes Mellitus. Obstetrics and gynecology. 2017;130(1):e17-e37. 